\title{
Measuring Ethnic Identification and Attachment in sub-Saharan Africa
}

\author{
Yoku Shaw-Taylor \\ NORC at the University of Chicago
}

In the past six years, methodological efforts to frame the issue of weak states have led to indices that rank states on the bases of a range of social, political, economic and security variables. Contestations and violent intercommunal conflict in Chad, Cote d'Ivoire, the Democratic Republic of the Congo, Kenya, Liberia, Nigeria, Rwanda, Sierra Leone, Somalia, Sudan and Zimbabwe or so-called 'trouble spots' in Africa (to quote a recent article in the Washington Post Baker 2008: A17), are evidence of the chasms and domestic anarchy in countries that have been described variously as weak, failing or collapsed.

A recent version of these indices is the Index of State Weakness in the Developed World published by Brookings Institution and prepared by Susan Rice and Stewart Patrick (2008); their work relies on a set of indicators to characterize all aspects of state weakness. Other examples include the Fragile States Briefs produced by Country Indicators for Foreign Policy Project at Carleton University that begun in 2006; State Fragility Index (2007) produced by Monty Marshall and Jack Goldstone at George Mason University; Failed States Index which started in 2005 and is produced by the Fund for Peace. These reports are based on an array of indicators including social, economic, political, security, crime, human development or social welfare and environment which are combined to create a composite score of state performance. Variations of the index methodology also include the report (2004) released by the Commission on Weak States and US National Security, which discusses threats of weak states to the US, and the Ibrahim Index of African Governance at the Harvard University Belfer Center for Science and International Affairs (2007), which focuses on 'political goods' such as safety and security, rule of law, transparency and corruption, participation and human rights, sustainable economic opportunity and human development. The Peace and Conflict Instability Ledger developed at the University of Maryland (Hewitt, Wilkenfeld and Gurr 2008) is an exemplar of these indexes. The conceptual frame is a familiar one: the incidence of instability or armed conflict can be forecasted if we know the extent of democracy, economic freedom, social development, militarization and regional armed conflict.

Generally, these indexes are based on models that relate collapses in the economy and civil society to major violent intercommunal conflict such as domestic unrests, riots, insurgencies, armed conflicts, civil conflicts or wars. State weakness, failure and eventual collapse are also catalyzed by another critical dimension: the proliferation of small arms (Klare 1994, 2004).

A latent variable in these constructs is ethnic differences: the recognition that ethnic (and religious) enmity is correlated with the incidence of intercommunal conflict or wars and state weakness. Rotberg $(2004,5)$ thinks that "civil wars ... usually stem from or have roots in ethnic, religious, linguistic or other intercommunal enmity'. The 'fear 
of the other that drives so much of ethnic conflict stimulates and fuels hostilities between regimes'.

But, the role of ethnic differences or a certain ethnic enmity in intercommunal conflict is indeed a puzzling one; when long-time neighbours become enemies overnight based on ethnic or religious affiliation or loyalty is this in response to state breakdown? When long-time neighbours become marauding killers overnight, isn't this the result of a collapse of state authority, rather than merely the result of deepseated ethnic or religious enmity? But if there were no underlying ethnic or religious differences or enmity, why the seemingly precipitous change in social relations and interactions? As Nelson Kasfir $(2004,54)$ argues, there is 'more probably going on than can be accounted for by the cultural or ideological cleavages that predate outbreaks of violence' in the countries experiencing intercommunal conflict.

My research argument is that if ethnic differences - what we know also in subSaharan Africa as a certain latent 'tribalism' - are to blame for community conflicts, it is predicated on a certain level of metaphorical social distance ${ }^{1}$ between social groups, or its proxy measures, ethnic identification and attachment. I use ethnic identification and attachment as proxy measures because precise social distance data are currently unavailable for sub-Saharan Africa. In this paper, I write about the results of differences in terms of ethnic identification and ethnic attachment in a sample of subSaharan countries (for which there are data). I pose the following research questions: what do these measures tell us about the strength of ethnicity? And does this construct add to our understanding of the role of tribalism in intercommunal conflict in the region? Let me give a background to this argument.

\section{Ethnic Differences and the Role of Small Arms in Intercommunal Conflict}

We are aware that a key variable in understanding the nature of armed conflict is the level of unregulated small arms and light weapons circulating freely on the black market since the end of the Cold War. Gamba (1998), Lumpe (2000) and Boutwell and Klare (2000) among others, have written about the role of illegal small and light weapons moving unchecked across porous borders globally. During the Cold War, arms transfers were made from government to government under the patronage of super powers. After the Cold War and since the 1980s, arms are transferred from government to self-styled insurgents and guerrilla movements facilitated by globalization and stockpiles of arms left over from the Cold War (Small Arms Survey 2001, 2006). These weapons are readily available because they are inexpensive, portable, easy to conceal and use (Klare 1999).

In the movie, Lord of War (2005), inspired by actual events and starring Nicholas Cage, the global networks of illegal arms trading are starkly rendered; recently, a widely publicized arrest of a Russian linked to the trade was made in Thailand (March 2008). The question, however, is: what is the relationship between official state stockpiles and availability of (licit and illicit) small arms in any community? The Small Arms Survey (2006) argues that in 'poorer' states where security is weak and governments are unstable, stockpiles of arms make armed conflict more likely. There is some recognition that the licit and illicit commerce in small arms are related; this is because arms that are acquired and exported legally, but not adequately monitored eventually find their way on the black market. While the Small Arms Survey estimates 
the volume of illegal arms circulating in sub-Saharan African and globally, it is difficult to ascertain the flows of these arms and to intercept them prior to the incidence of armed conflict in any particular country; it is only when community tensions become full blown armed conflicts that our collective attentions are drawn to the existence of these weapons.

The availability of these weapons encourages warfare or violence as a method of conflict resolution. And when there are any community differences (cultural/ethnic, social, economic or political), these inexpensive and portable weapons only worsen community clashes by extending the duration of violence.

The ethnic diversity and heterogeneity in Africa does not necessarily have to be baneful; like any region, these diverse African cultures have lived in harmony and experienced conflict; however, the finding that cultural differences are significantly related to intercommunal conflict (Atiku-Abubakar and Shaw-Taylor 2003) in subSaharan Africa suggests a residual persistence of perceptions of ethnic superiority (from the pre-independence era) rather unlike racism in its economic and political outcomes (inequities); in that, patronage based on family and kinship ties and networks of ethnic interest trump other networks in society. This phenomenon of ethnocentrism is analogous to the historical phenomenon of 'tribalism,' with its baggage of adherence to tradition and allegiance to tribal identification (Young 1994, Glickman, 1995).

The immediate pre-independence period focused efforts on building nationalism and nation-states comprising various ethnic groups; this programme of modern nationstates and nationalists was less focused on ethnic patronage (Davidson 1992, Apter and Rosberg 1994). The argument was that so-called 'tribal unions' or 'tribal associations' did not have any place in the emergent post-colonial nations; the new nationalism was based on a progressive ideal of a community of diverse ethnic groups and the 'savage backwoods, ${ }^{2}$ of the pre-colonial era was to be abandoned. There was tension between the so-called traditionalists, the chiefs and the favoured citizens of the pre-colonial ethnic nations and the new nationalists as these newly African countries gained independence. The realities of social conflict were apparent; Davidson (1992:111), for instance, notes that the 'new political parties (being formed in the African countries) drew authentic and sometimes overwhelming popular support from their ethnic roots'. Independence movements that once acted in the name of national independence grappled with the potential of devolving into ethnic sub-divisions. The postindependence period therefore, became a project tracking the challenges of nationalism and the hydra of ethnic allegiances (Rothchild 1997, Kieh and Mukenge 2002, Nnoli 1998, Irobi 2005). The challenge then, was how to mitigate the role of ethnic loyalty or tribalism in the immediate post-independence nationalist project. The challenge now, is how to mitigate the flow of small arms so that ethnic differences, where they exist, do not become full-blown violent and tragic conflicts pitting ethnic groups against one another.

\section{Data \& Methods}

I use country-merged data from Afrobarometer surveys conducted from 1999 to 2001 (round 1) and in 2004 (round 2). Since 1999, Afrobarometer surveys have been an important source of survey data in Africa on public attitudes about democracy, governance, public services, and economy; but data on the conventional measures of 
social distance were not collected in rounds 1 and 2. The surveys use clustered stratified multi-stage area probability samples of citizens 18 years or older. Respondents are administered face-to-face interviews based on a structured questionnaire. ${ }^{3}$ Twelve countries were surveyed in round 1 including Botswana, Ghana, Lesotho, Malawi, Mali, Namibia, Nigeria, South Africa, Tanzania, Uganda, Zambia and Zimbabwe yielding a sample size of 19,527; for round 2, four more countries were added: Cape Verde, Kenya, Mozambique and Senegal yielding a sample size of 24,248. A minimum sample size of 1,200 cases (or slightly less) was selected for each country; larger sample sizes were drawn from Nigeria Uganda, Kenya and South Africa. ${ }^{4}$ The surveys are conducted through a collaboration of social scientists in African countries. The project is coordinated by the Institute for Democracy in South Africa (Idasa), the Center for Democratic Development (CDDGhana) and Michigan State University. The project has received funding from the Swedish International Development Cooperation Agency, the Netherlands Ministry of Foreign Affairs, the US Agency for International Development, the Danish Ministry of Foreign Affairs, and the Department of International Development (UK).

Importantly, the multi-stage area probability sample design uses probability proportionate to population size method. Each country sample is stratified by key social characteristics in the population such as sub-national area (e.g. region/province) and residential locality (urban or rural). The area stratification reduces the likelihood that distinctive ethnic or language groups are left out of the sample (emphasis mine). And the urban/rural stratification is a means to make sure that these localities are represented in their correct proportions' (Afrobarometer Sampling document: http://www.afrobarometer.org/sampling.html; accessed April 2008). This is important for our analytical purposes to ensure that country samples contain the spread of ethnic groups and that all ethnic groups are represented.

A review of the questionnaire yielded the following items for analytic purposes; in round 1, these include:

(1) 'Besides being (insert nationality), which specific group do you feel you belong to first and foremost'. This is a root identification question. This 'identification' question is open-ended and responses were post-hoc classified into 15 categories which included the core categories of ethnicity, race, religion, occupation, class, gender, party, and continental.

(2) 'Of all groups in this country, (members of your identity group) are the best.' This item is a dimension of ethnic attachment - this 'group is best' question uses Likert scale responses.

(3) 'You feel much stronger ties to (members of your identity group) than to other (people of your nationality)?' This item is the other measure of ethnic attachment. This 'stronger ties to group' question uses Likert scale responses.

Curiously and inexplicably, the items ' $g r o u p ~ i s ~ b e s t$ ' and 'stronger ties to group' were not asked of respondents in Ghana, Mali, Tanzania and Uganda in round 1. The root question item about identity was not asked of respondents in Ghana.

In round 2, the 'group is best' question was not fielded, and the 'stronger ties to group' item was revised to read: 'Which of these two groups do you feel most strongly attached to: group or national identity?' I recoded the 'stronger ties to group' item from 
round 1 to be dichotomous as was done in round 2. The root question 'identification' in round 2 was not revised. To fit a general linear model, I recoded the 'group is best' and the 'identification' variables in both rounds to be dichotomous as well.

I hypothesize that countries that have had intercommunal conflict would have significantly higher proportions of respondents choosing tribal or ethnic identification and attachment (besides nationality). Specifically, I argue that the countries described as 'trouble spots' (for which there are data) including Kenya, Nigeria and Zimbabwe will show higher proportions of respondents reporting tribal or ethnic identification and attachment when compared to the other countries in the sample. I argue that if this is the case, these countries may be arguably more tribalistic or ethnocentric when compared to the others.

Now, this research design is bounded by the fact that ethnic identification and attachment could be the result of past ethnic violence and conflict. In which case, attachment to ethnicity or tribalism may actually be the outcome (not the cause) of (past) ethnic violence. Ideally, of course, this can be tested only with an experimental (or quasi-experimental) design, where we would capture ethnic identification and attachment pre and post conflict. I do not attempt to achieve such a design in this study. Rather, I use a correlational design that does not make any declarations about causality.

I used reliability analysis to assess whether the two questionnaire items from survey round 1, group is best and stronger ties to group have a common attachment factor. I used frequency distributions and the contrasts function in the GENMOD procedure in SAS to test whether proportions of respondents in each country are significantly different based on ethnic identification, and those who say their ethnic group is best or who say they have stronger ties to their ethnic group. In round 2 (2004), the tests were repeated but only for ethnic identification and respondents who have stronger ties to their group. The GENMOD procedure is appropriate because it allows for the estimation of user-defined contrasts in a linear model through a nonlinear link function when the response or dependent variable is non-continuous (in this case, dichotomous) and the predictor (independent) variable is categorical. This procedure is based on the normal approximation for proportions. I used the binomial distribution option and asked for test of differences among least squares means.

\section{Findings}

Cronbach's alpha yielded a coefficient of 0.9 indicating that we cannot reject my contention that group is best and stronger ties to group measure a common factor I call (ethnic) attachment. A high alpha coefficient means the items are positively correlated. Table 1 presents data from round 1 showing ethnic identification or percent of respondents choosing ethnic group or tribe as main identity group besides nationality. Generally, most respondents in surveyed countries in this round chose sub-national identities when asked to identify one, but in Botswana, 32.9 percent or 1 out of 3 respondents chose not to differentiate by sub national group. By comparison, in each of the other countries less than two percent of respondents chose not to differentiate by ethnicity/tribe, religion, gender or occupation. 
Table 1: Besides nationality, which specific identity group do you feel you belong to first and foremost?

\begin{tabular}{llll} 
Country & Tribe/Ethnicity & Identity Group with highest \% \\
\hline Botswana & $28.9 \%$ & Won't differentiate, 32.9 \\
Lesotho & 1.9 & Occupation & 32.8 \\
Malawi & 39.1 & Tribe/Ethnicity & \\
Mali & 38.5 & Tribe/Ethnicity & \\
Namibia & 43.0 & Tribe/Ethnicity & \\
Nigeria & $47.4^{*}$ & Tribe/Ethnicity & \\
South Africa & 21.6 & Tribe/Ethnicity & \\
Tanzania & 3.0 & Occupation, & 76.4 \\
Uganda & 11.8 & Occupation, & 62.0 \\
Zambia & 7.7 & Religion, & 32.9 \\
Zimbabwe & $36.0 *$ & Tribe/Ethnicity & \\
$\mathrm{p}<.01 /$ & &
\end{tabular}

In this round, less than a tenth of respondents in three countries, Lesotho, Tanzania and Zambia (1.9, 3 and 7.7 percent respectively) chose ethnicity or tribe as their identification group other than nationality. In Uganda, ethnic identification is also comparatively low. In these countries, more respondents chose occupation or religion for identification. But, notably, approximately one out of two respondents in Nigeria (47.4 percent) and Namibia (43 percent) chose tribe or ethnicity. Approximately one out of three (36 percent) Zimbabweans chose ethnicity. The proportion for Nigeria is significantly higher when compared to all the other countries except Namibia. The proportion for Zimbabwe is significantly higher when compared to Lesotho, South Africa, Tanzania, Uganda and Zambia, but not significantly higher or different in comparison to Botswana, Malawi, Mali and Namibia.

Results in table 2 are based on the sub-sample of respondents who chose ethnic identification besides nationality (from table 1). In this table, Nigeria emerges as the country with significantly higher proportions of respondents expressing attachment to ethnic group when compared to Malawi, Namibia, South Africa and Zimbabwe (all countries with comparatively higher proportions of respondents choosing ethnic identification - see table 1). The proportion of Zimbabweans saying their ethnic group is best is not significantly higher when compared to Malawi (but the estimate is significantly lower than in Namibia and South Africa). The proportion of Zimbabweans expressing stronger ties to their ethnic group is significantly higher when compared to Malawi, (but again, this estimate is significantly lower than in Namibia and South Africa). 
Table 2: Attachment to Ethnic Group Identity

\begin{tabular}{lll} 
Country & $\begin{array}{l}\text { Of all groups in this } \\
\text { country, members of } \\
\text { your ethnic group are } \\
\text { the best }\end{array}$ & $\begin{array}{l}\text { You feel much stronger } \\
\text { ties to ethnic group } \\
\text { than to other nationals } \\
\text { of country }\end{array}$ \\
\hline Malawi & 46.9 & 67.9 \\
Namibia & 67.3 & 75.7 \\
\hline Nigeria & $87.3^{*}$ & $91.6^{*}$ \\
South Africa & 70.9 & 78.3 \\
Zambia & 50.4 & $69.8^{*}$ \\
\hline$* \mathrm{p}<.01$ & &
\end{tabular}

In round 2, the analysis was expanded to include 16 countries. Like table 1 , table 3 shows percent of respondents choosing ethnic group or tribe as main identity group besides nationality. Clearly, more respondents in more countries chose occupation rather than tribe or ethnic group when asked about attachments to social group in this survey round; this includes one of the countries of interest, Kenya, where, approximately one out of three made this choice. And in Zimbabwe approximately one out of every three respondents chose religion when asked about attachments to social group. Note that while the proportion of respondents in Nigeria, the first country of interest, in this survey is comparable to the previous round (47.4 percent in round 1 versus 49.3 percent in round 2), the proportion of Zimbabweans has dropped by 25 percent (36 percent in round 1 versus 10.9 percent in round 2). In fact, the proportions of respondents choosing ethnic identification (besides nationality) in Zimbabwe together with South Africa (10.8 percent), Zambia (13.3 percent) and Cape Verde (1.1 percent) were the lowest among the countries in this survey round. Although the proportion in Zambia has almost doubled, it is still among the lowest.

There are some notable increases in proportions of respondents choosing ethnic or tribal identification as well. Lesotho and Tanzania which had previously reported low proportions of respondents choosing ethnic identification in round 1 are reporting increases of 53.7 percent and 23.3 percent respectively in round 2. In Botswana, 53.7 percent of respondents now choose ethnic identification, an increase of almost 25 percent. There are notable decreases as well; proportions in Malawi and Namibia declined by over 20 percent and in South Africa, the proportion decreased by almost 11 percent.

Table 3: Besides nationality, which specific identity group do you feel you belong to first and foremost?

\begin{tabular}{|c|c|c|c|}
\hline Country & Tribe/Ethnicity & $\begin{array}{l}\text { Change from } \\
\text { Round } 1\end{array}$ & $\begin{array}{l}\text { Group identity with } \\
\text { highest \% }\end{array}$ \\
\hline Botswana & $53.7 \%$ & $24.8 \%$ & Tribe/Ethnicity \\
\hline Ghana & 39.4 & & Tribe/Ethnicity \\
\hline Lesotho & 55.6 & 53.7 & Tribe/Ethnicity \\
\hline Malawi & 14.8 & -24.3 & Occupation, \\
\hline Mali & 36.0 & -2.5 & Tribe/Ethnicity \\
\hline
\end{tabular}




\begin{tabular}{lllll} 
Country & Tribe/Ethnicity & $\begin{array}{l}\text { Change from } \\
\text { Round 1 }\end{array}$ & \multicolumn{2}{l}{$\begin{array}{l}\text { Group identity with } \\
\text { highest \% }\end{array}$} \\
\hline Namibia & 20.9 & -22.1 & Gender, & 33.6 \\
Nigeria & $49.3^{*}$ & 1.9 & Tribe/Ethnicity & \\
South Africa & 10.8 & -10.8 & Occupation, & 31.0 \\
Tanzania & 26.3 & 23.3 & Occupation, & 52.5 \\
Uganda & 20.2 & 8.4 & Occupation, & 55.2 \\
Zambia & 13.3 & 5.6 & Religion, & 25.8 \\
Cape Verde & 1.1 & & Occupation, & 30.1 \\
Kenya & $19.4^{*}$ & & Occupation, & 55.6 \\
Mozambique & 28.9 & & Occupation, & 46.2 \\
Senegal & 33.8 & & Occupation, & 44.8 \\
\hline
\end{tabular}

$* \mathrm{p}<.01$

The proportion of Nigerians choosing ethnic identification is significantly higher when compared to the other countries, except for Botswana and Lesotho. Of the other two countries of interest, Kenya and Zimbabwe, only 19.4 percent and 10.9 percent of respondents chose tribe or ethnic identification besides nationality; that is approximately one out five respondents chose ethnicity or tribe in Kenya and approximately one out of ten chose tribe in Zimbabwe; note the difference in the proportions choosing ethnicity or tribe from round 1. The proportions of Zimbabweans choosing ethnic identification is significantly lower when compared to all the other countries except South Africa and Cape Verde, and the proportions of Kenyans choosing ethnic identification is significantly lower when compared to all other countries except Malawi, South Africa, Zambia, Zimbabwe and Cape Verde.

\section{Table 4: Attachment to Ethnic Group Identity}

\begin{tabular}{ll} 
Country & $\begin{array}{l}\text { Most strongly attached to } \\
\text { ethnic group identity }\end{array}$ \\
\hline Botswana & $51.7 \%$ \\
Ghana & $35.1 \%$ \\
Lesotho & $18.9 \%$ \\
Mali & 54.7 \\
Nigeria & $49.7 *$ \\
\hline$* \mathrm{p}<.01$ &
\end{tabular}

Similar to table 2, results in table 4 are restricted to countries where more respondents chose ethnic identification besides nationality (from table 3); compared to the other countries, the estimate of respondents in Nigeria is significantly higher than in Ghana and Lesotho, but not in Botswana or Mali.

\section{Discussion and Conclusion}

Results from these analyses are mixed; we cannot reject the hypotheses when it comes to Nigeria, but our hypotheses do not hold for Kenya and Zimbabwe. In the first survey round, while results from Nigeria allow us to maintain the hypotheses of greater ethnic 
identification and attachment, Zimbabwe's rates of ethnic identification were only significantly different for countries where ethnic identification was low (except South Africa). For ethnic attachment, the results for Zimbabwe are not conclusive and so I cannot say that Zimbabwe has higher rates of ethnic attachment. In round 2, Nigeria again confirms the hypotheses, but here again, the hypotheses of higher rates of ethnic identification and attachment do not hold for Kenya and Zimbabwe.

Nigeria is an exemplar of the ethnic identification and attachment as evidenced by their post-colonial history and past conflicts (for example, the Biafran war) and the current insurgency in the Niger Delta. But the cases of Kenya and Zimbabwe need explication.

In news reports (Gettleman 2008, New York Times), the recent (January-March, 2008) conflicts in Kenya were attributed to ethnic enmity or differences as members of Kikuyu and Luo ethnic groups visited violence on each other. My analyses show that most Kenyans do not identify themselves ethnically or tribally; so what explains the ethnic violence? What my analyses don't do is investigate the interaction of socioeconomic class and ethnicity or tribal attachment. Since more Kenyans identify themselves by occupational group, a reasonable next step would be to look into how class differences interact with ethnic or tribal differences.

It is not clear that the conflict in Zimbabwe is based on ethnic or tribal differences; the rates of ethnic attachment, especially, in both survey rounds were not remarkable. Although Mugabe's regime has been accused of complicity in the deaths of thousands of members of the Ndebele ethnic group in 1983, the current turmoil stems from governmental or political intransigence and an economy crippled by a messy land redistribution programme. The results of the analyses suggest that a mapping of the root causes of the conflict in Zimbabwe perhaps should begin with an in-depth examination of the structure of political power and the distribution of 'political goods' in Zimbabwe and not ethnic or tribal differences or enmity.

It is noteworthy that only three of the countries experiencing intercommunal conflict are included in this study; data from Chad, Côte d'Ivoire, DR Congo, Liberia, Rwanda, Sierra Leone, Somalia and Sudan would provide more opportunity to test and hone the hypotheses.

There are other intriguing findings here; while the rate of respondents choosing ethnicity did not change for Nigeria and Mali, in Botswana, Lesotho and Tanzania, ethnic identification increased markedly from round 1 to round 2. In Malawi, Namibia and Zimbabwe, ethnic identification declined considerably between survey rounds. It is not clear what caused these rates to change or if we should be concerned about them, and whether or not these rate changes may indicate non-sampling errors in the design of the surveys.

The analyses shows Zambia to be the least ethnocentric or tribalistic; in Zambia, ethnic identification and attachment is minimal, and this is not for want of different ethnic or tribal groups. In both rounds, less than 14 percent of respondents expressed ethnic identification or attachment. A closer study of Zambia's ethno-social landscape would inform this discourse. Ghana and Mali (in both rounds) are interesting cases because they have comparatively high rates of ethnic identification and attachment, but have been able to avoid intercommunal conflict. 
Finally, although considerable progress has been made in describing weak states, identifying their characteristics and predicting their political instability, what is lacking, I argue, is a mapping of exactly how ethnicity or tribalism, or precisely, social distance between ethnic groups contributes to community violence. The results from this analyses show that this role is nuanced and tribalism or ethnocentrism cannot always be fingered singularly in intercommunal conflicts - at best, tribalism interacts with other factors to create conflicts (compare Kenya and Zimbabwe). A precise measurement of ethnic social distance will help us distil its main effect and allow us to make predictions about the level of ethnic antipathies or antagonisms before they blow up into tragic violent confrontations. The Afrobarometer surveys provide a platform for measuring ethnic social distance in sub-Saharan Africa.

\section{Notes}

1. The conventional social distance scale developed by Emory Bogardus (1926) was derived from the dual conceptual foundations of geometric (spatial) and metaphoric distance although a precise measurement of geometric distance is suppressed in the Bogardus scale (Ethington 1997). At any rate, the social distance scale remains one of the enduring and successful concepts in sociology, and Bogardus's original version yielded a 'racial distance quotient' measured on a seven point cumulative scale that showed the extent to which respondents would accept a member of a racial out-group. A score of 1.00 indicates no social distance. The cumulative questions are as follows: Would willingly admit members of each race: (1) To close kinship by marriage; (2) To my club as personal chums; (3) To my street as neighbours; (4) to employment in my occupation in my country, (5) To citizenship in my country; (6) As visitors in my country, (7) Would exclude from my country. As reported by Philip Ethington (1997) this scale or some modification of it, has been applied in over 300 studies of gender, class or status, to examine social distance or social relations.

2. Basil Davidson (1992), page 113, quoting Attoh Ahuma's 1911 book The Gold Coast and the National Consciousness.

3. The latest full questionnaire is obtainable at: http://www.afrobarometer.org/questionnaires/

4. Sample sizes for each country are as follows:

$\begin{array}{lll}\text { Botswana } & \text { Round2 } & \text { Round1 } \\ \text { Ghana } & 1,200 & 1,200 \\ \text { Lesotho } & 1,200 & \\ \text { Malawi } & 1,200 & 1,177 \\ \text { Mali } & 1,200 & 1,208 \\ \text { Namibia } & 1,283 & 2,089 \\ \text { Nigeria } & 1,199 & 1,183 \\ \text { South Africa } & 2,428 & 3,603 \\ \text { Tanzania } & 2,400 & 2,200 \\ \text { Uganda } & 1,223 & 2,198 \\ \text { Zambia } & 2,400 & 2,271 \\ \text { Zimbabwe } & 1,198 & 1,198 \\ \text { Cape Verde } & 1,104 & 1,200 \\ \text { Kenya } & 1,268 & \\ \text { Mozambique } & 2,398 & \\ \text { Senegal } & 1,400 & \\ & 1,147 & \end{array}$




\section{References}

Afrobarometer Surveys, 2008, http://www.afrobarometer.org, accessed March 3, 2008.

Atiku-Abubakar, Jennifer, J. and Yoku Shaw-Taylor, 2003, 'An Empirical Profile of Weak States in Sub-Saharan Africa’, Africa Development, XXVIII (3\&4): 168-185.

Baker, Peter, 2008, 'Bush, in Africa, Issues Warning to Kenya', Washington Post: February 17: A17.Belfer Center for Science and International Affairs, 2007, Ibrahim Index of African Governance. Cambridge, MA: Harvard University.

Bogardus, Emory S., 1926, 'Social Distance in the City', Proceedings and Publications of the American Sociological Society. 20:40-46.

Boutwell, Jeffrey and Michael Klare, 2000, 'Waging a New Kind of War: A Scourge of Small Arms', Scientific American 282 (6): 48-53.

Commission on Weak States and US National Security, 2004, On the Brink: Weak States and US National Security, Washington, DC: Center for Globa Development.

Country Indicators for Foreign Policy, 2007, Failed and Fragile States. Ottawa, Ontario: Carleton University.

Davidson, Basil, 1992, The Black Man's Burden: Africa and the Curse of the Nation-State. New York: Random House.

Ethington, Philip J., 1997, 'The Intellectual Construction of Social Distance: Toward a Recovery of Georg Simmel's Social Geometry'. Electronic edition of European JournalofGeography.30: http://www.cybergeo.presse.fr/essoct/texte/socdis.htm, accessed May 1, 2008.

Fund for Peace 2006, Failed States Index, Washington DC. http://www.fundforpeace.org, accessed April 15, 2008.

Gamba, Virginia, 1998, 'Small Arms Foster Social Turmoil: Illegal Trafficking Disrupts African Communities, Spreads Crime', Africa Recovery 12 (August): 24.

Gettleman, Jeffrey, 2008, 'Signs in Kenya of a Land Redrawn by Ethnicity', New York Times: February 15:A1.

Glickman, Harvey, ed., 1995, Ethnic Conflict and Democratization in Africa. Atlanta: GA: African Studies Association Press.

Hewitt, J. Joseph, Jonathan Wilkenfeld and Ted Robert Gurr, 2008, Peace and Conflict 2008. Center for International Development and Conflict Management. College Park, MD: University of Maryland.

Irobi, Emmy, 2005, Ethnic Conflict Management in Africa: A Comparative Case Study of Nigeria and South Africa. Parker, CO: Outskirts Press.

Kasfir, Nelson, 2004, 'Domestic Anarchy, Security Dilemmas and Violent Predation: Causes of Failure', pp. 53-76, in When States Fail: Causes and Consequences edited by Robert I. Rotberg. Princeton, NJ: Princeton University Press.

Kieh, George Klay and Ida Rousseau Mukenge, eds., 2002, Zones of Conflict in Africa: Theories and Cases. Westport, CT: Praeger Publishers.

Klare, Micheal T., ed., 1999, Light Weapons and Civil Conflict. Lanham, MD: Rowman and Littlefield.

Klare, Micheal T., 2004, 'The Deadly Connection: Paramilitary Bands, Small Arms Diffusion and State Failure', pp. 116-134, in When States Fail: Causes and Consequences, edited by Robert I. Rotberg. Princeton, NJ: Princeton University Press.

Lumpe, Lora, ed., 2000, Running Guns: The Global Black Market in Small Arms. New York: Zed Books. 
Marshall, Monty G. and Jack Goldstone, 2007, 'Global Report on Conflict, Governance and State Fragility', Foreign Policy Bulletin 17 (March):3-22.

Nnoli, Okwudiba, ed., 1998, Ethnic Conflicts in Africa. Dakar, Senegal: Codesria.

Rice, Susan E. and Stewart Patrick, 2008, Index of State Weakness in the Developing World. Washington, DC: The Brookings Institution.

Rotberg, Robert I., ed., 2004, 'The Failure and Collapse of Nation-States: Breakdown, Prevention and Repair', pp. 1-50, in When States Fail: Causes and Consequences, edited by Robert I. Rotberg. Princeton, NJ: Princeton University Press.

Rothchild, Donald, 1997, Managing Ethnic Conflict: Pressures and Incentives for Cooperation, Washington, DC: Brookings Institution Press.

Small Arms Survey, 2001, Profiling the Problem. Geneva: Graduate Institute of International Studies.

Small Arms Survey, 2006, Unfinished Business. Geneva: Graduate Institute of International Studies.

Young, Crawford, 1994, 'Evolving Modes of Consciousness and Ideology: Nationalism and Ethnicity', pp. 61-86, in Political Development and the New Realism in Sub-Saharan Africa, edited by David E. Apter and Carl G. Rosberg. Charlottesville, VA: University Press of Virginia. 